\title{
STUDI EKOLOGI TUMBUHAN SAGU (Metroxylon spp) DALAM KOMUNITAS ALAMI DI PULAU SERAM, MALUKU
}

\author{
Ecology Study of Sago Palm (Metroxylon spp) in the Natural Community \\ at the Seram Island, Maluku \\ Samin Botanri ${ }^{1}$, Dede Setiadi ${ }^{2}$, Edi Guhardja ${ }^{2)}$, Ibnul Qayim ${ }^{2)}$, \\ dan/and Lilik B. Prasetyo ${ }^{3)}$ \\ ${ }^{1)}$ Fakultas Pertanian Universitas Darussalam Ambon \\ Jln. Raya Tulehu Km. 24, Ambon 97582 \\ ${ }^{2)}$ Departemen Biologi FMIPA Institut Pertanian Bogor, Kampus IPB Darmaga, Bogor 16680 \\ Jln. Agatis Gedung Fapet Wing 1 Lt. 5. Telp/Fax. (0251) 8622833 \\ ${ }^{3)}$ Departemen KSH dan Ekowisata Fak. Kehutanan Institut Pertanian Bogor \\ Kampus IPB Darmaga, Bogor 16680 \\ Jln. Lingkar Akademik Telp. (0251) 8621947. Fax. (0251) 8621947
}

Naskah masuk : 1 Juli 2010; Naskah diterima : 22 Mei 2011

\begin{abstract}
Sago palm (Metroxylon spp) is a tropical plant adapted to marginal land such as fresh water swamp, peat swamp or brackish water. The aim of this research were to : (1) analys conducted to describe of sago palm characteristic in the nature community, (2) identify habitat preference of sago palm, (3) to describe interaction between sago palm and environmental factors, and (4) identify the sago palm trees potential and sago flour production at three areas in the Seram Island, Maluku. The research was conducted in March to November 2009. The result of research showed that population structure of sago palm in the nature community follows young growth pattern with seedling death of about $85 \%$. It was found that there are five of the sago palm species namely tuni, makanaro, sylvestre, rotang, and molat. Tuni species is the most dominant vegetation which cover $43.3 \%$ of habitat. Swamp condition as adaptation strategy more amount of sago palm roots directed out to water surface. In sago palm community there was negative interspecific association with Jaccard index $<0.2$. Among the environmental condition, sun light intensity, cation exchange capasity (CEC), and calcium in water were the most factor. The potential clump population at the Seram Island is about 3,2 million clumps, which of about 1.5 million trunk of trees. Tuni and sylvestre are the most potential species with production capacity of about 566.04/kg by 560.68 $\mathrm{kg} /$ trunk.
\end{abstract}

Keywords: Adaptation, environmental factor, Seram Island, habitat type, sago palm

\begin{abstract}
ABSTRAK
Sagu (Metroxylon spp) merupakan tumbuhan palem tropika basah, memiliki adaptasi kuat untuk tumbuh pada lahan marjinal seperti lahan tergenang air tawar, lahan gambut, dan air payau. Penelitian bertujuan : (1) melakukan analisis untuk menjelaskan sifat pertumbuhan sagu dalam komunitas alami, (2) mengungkapkan preferensi habitat tumbuhan sagu, (3) melakukan analisis interaksi tumbuhan sagu dengan faktor lingkungan, dan (4) mengungkapkan potensi tegakan dan produksi pati sagu. Penelitian berlangsung di tiga wilayah di pulau Seram, Maluku secara keseluruhan, tentu dengan menggunakan sampling, bukan menggunakan metode sensus pada bulan Maret-Nopember 2009. Hasil penelitian menunjukkan bahwa struktur populasi sagu dalam komunitas alami mengikuti pola pertumbuhan muda dengan tingkat kematian pada fase semai sekitar $85 \%$. Di Pulau Seram terdapat lima jenis sagu yaitu tuni, makanaro, sylvestre, rotang, dan molat. Sagu tuni merupakan spesies dominan dengan penguasaan habitat mencapai $43,3 \%$. Serta memiliki daya adaptasi yang tinggi pada berbagai tipe habitat. Dalam beradaptasi dengan kondisi habitat tergenang, perakaran sagu mengalami modifikasi arah
\end{abstract}


pertumbuhan menuju permukaan air dengan jumlah yang lebih banyak. Dalam komunitas sagu terjadi asosiasi antarspesifik secara negatif dengan Jaccard indeks $<0,2$. Variabel iklim, tanah, dan kualitas air rawa yang memiliki peran kuat dalam pertumbuhan sagu masing-masing adalah intensitas cahaya surya mikro, kapasistas tukar kation (KTK), dan kandungan kalsium air. Di Pulau Seram terdapat potensi populasi rumpun sagu sekitar 3,2 juta rumpun dengan jumlah tegakan fase pohon mencapai 1,5 juta batang. Jenis sagu tuni dan sylvestre merupakan jenis sagu potensial dengan kapasitas produksi masingmasing $566,04 \mathrm{~kg}$ dan $560,68 \mathrm{~kg} / \mathrm{batang}$.

\section{Kata kunci : Adaptasi, faktor lingkungan, Pulau Seram, tipe habitat, tumbuhan sagu}

\section{PENDAHULUAN}

\section{A. Latar Belakang}

Sagu (Metroxylon spp) salah satu tumbuhan dari keluarga palmae wilayah tropik basah. Secara ekologi, sagu tumbuh pada daerah rawa-rawa air tawar atau daerah rawa bergambut, daerah sepanjang aliran sungai, sekitar sumber air, atau hutan-hutan rawa. Habitat tumbuh sagu dicirikan oleh sifat tanah, air, mikro iklim, dan spesies vegetasi dalam habitat itu. Berdasarkan informasi tempat tumbuh sagu yang cukup bervariasi tersebut, maka dapat dikatakan bahwa tumbuhan sagu mempunyai daya adaptasi yang tinggi (Suryana, 2007). Secara umum terdapat lima jenis sagu yang tumbuh dalam komunitas alami maupun budidaya yaitu sagu tuni, makanaro, ihur, duri rotang, dan molat (Louhenapessy, 2006). Studi ekologi sagu yang selama ini telah dilakukan masih memerlukan suatu penelitian tentang autekologinya yaitu struktur populasi, kelimpahan spesies, penentuan preferensi ekologi seperti tipe habitat, interaksi spesies dengan tipe habitat, mekanisme adaptasi, interaksi dengan parameter ingkungan, dan potensi tumbuhan sagu.

Berkaitan dengan hal tersebut, maka kajian permasalahan dalam penelitian ini adalah : (1) bagaimana sifat pertumbuhan sagu dalam komunitas sagu alami?, (2) bagaimana preferensi habitat tumbuhan sagu?, dan (3) bagaimana interaksi antara tumbuhan sagu dengan faktor lingkungan?.

\section{B. Tujuan Penelitian}

Tujuan umum penelitian ini adalah melakukan studi ekologi tumbuhan sagu dalam komunitas sagu alami di Pulau Seram. Tujuan khususnya yaiu : (1) melakukan analisis untuk menjelaskan sifat pertumbuhan sagu dalam komunitas alami, (2) mengungkapkan preferensi habitat tumbuhan sagu, (3) melakukan analisis untuk menjelaskan interaksi tumbuhan sagu dengan faktor lingkungan, dan (4) mengetahui potensi tegakan dan produksi pati sagu di Pulau Seram (Wilayah Luhu Kabupaten Seram Bagian Barat, Wilayah Sawai Kabupaten Maluku Tengah, dan Wilayah Werinama Kabupaten Seram Bagian Timur), Maluku.

\section{BAHAN DAN METODE}

\section{A. Waktu dan Lokasi}

Penelitian berlangsung pada bulan Maret Nopember 2009, berlangsung di Pulau Seram, Maluku, antara lain Wilayah Luhu Kabupaten

Keterangan (Remarks) : $\bigcirc$ Lokasi sampling(Sampling location)

Gambar(Figure) 1. Peta lokasi penelitian Pulau Seram (Map of site research at the Seram Island) 
Seram Bagian Barat, Wilayah Sawai Kabupaten Maluku Tengah, dan Wilayah Werinama Kabupaten Seram Bagian Timur. Analisis tanah dan air dilakukan di laboratorium Balai Penelitian Tanah Bogor. Spesies tumbuhan yang tidak diketahui, diidentifikasi oleh ahli taksonomi dari Herbarium Bogoriense.

\section{B. Bahan dan Peralatan}

Penelitian menggunakan potensi tumbuhan sagu yang tersebar pada tiga wilayah di Pulau Seram, Maluku, yang merupakan ulangan yakni Wilayah Luhu Kabupaten Seram Bagian Barat, Wilayah Sawai Kabupaten Maluku Tengah, dan Wilayah Werinama Kabupaten Seram Bagian Timur. Suhu dan kelembaban relatif diukur menggunakan thermohigrometer, intensitas cahaya di bawah tegakan diukur menggunakan lux meter (light meter). Data iklim lokal diperoleh dari stasiun klimatologi Kecamatan Kairatu Kabupaten Seram Bagian Barat (SBB) dan Kecamatan Amahai Kabupaten Maluku Tengah (MT). Analisis data menggunakan perangkat lunak Ecological Methodology, SPSS ver. 15 dan Minitab ver. 15.

\section{Metode Penelitian}

\section{Penentuan Contoh}

\section{a. Plot Penelitian}

Wilayah sampel ditetapkan meng-gunakan metode judgement sampling/ purposive random sampling. Wilayah sampel terpilih yaitu Wilayah Luhu Kabupaten Seram Bagian Barat, Wilayah Sawai Kabupaten Maluku Tengah, dan Wilayah Werinama Kabupaten Seram Bagian Timur (SBT). Pengamatan vegetasi bawah (seedling) dilakukan pada petak berukuran $2 \mathrm{~m} \times 2 \mathrm{~m}$, sapling $5 \mathrm{~m}$ x $5 \mathrm{~m}$, tiang $10 \mathrm{~m} \times 10 \mathrm{~m}$, dan pohon $20 \mathrm{~m} \times 20 \mathrm{~m}$. Jumlah petak pengamatan sebanyak 131 plot. Pada setiap plot dibuat petak sesuai ukuran masing-masing. Petak pengamatan ditetapkan menggunakan metode garis berpetak (Kusmana, 1997).

\section{b. Lingkungan dan Tanah}

Suhu dan kelembaban udara relatif diukur pada pukul 07.30, 13.00, dan 17.00. Intensitas cahaya surya di bawah tegakan sagu, diukur antara pukul 11.00 - 14.00. Sampel tanah diambil pada kedalaman $0-30 \mathrm{~cm}$ dan $30-60 \mathrm{~cm}$. Sampel air rawa diambil dari habitat tergenang kemudian dianalisis kualitasnya. Salinitas ditetapkan menggunakan refraktometer.

\section{Parameter yang Diamati}

Pengamatan sagu dan vegetasi lain meliputi : jumlah rumpun, jumlah individu sagu menurut fase pertumbuhan, jenis vegetasi, jumlah individu spesies yang kedapatan pada setiap unit contoh, dan luas tutupan (coverage). Berdasarkan parameter tersebut, maka dilakukan :

\section{a. Analisis Vegetasi}

Analisis vegetasi dilakukan dengan menggunakan formula Cox (2002) : INP $=\mathrm{KR}+$ FR + DR. Kemudian ditetapkan Nisbah Jumlah Dominasi (NJD atau SDR summed dominanced ratio $)=\mathrm{INP} / 3(\%)$.

\section{b. Analisis Asosiasi Interspesifik}

Asosiasi interspesifik ditentukan menggunakan formula menurut Ludwig \& Reynolds (1988) dengan tahapan : (1) analisis Variance Ratio $(\mathrm{VR})$ menggunakan rumus : $V R=$ $S T^{2} / \delta T^{2}$; (2) analisis asosiasi spesies menggunakan rumus Chi-square, (3) tingkat asosiasi ditetapkan menggunakan indeks Jaccard (JI) : JI $=\mathrm{a} / \mathrm{a}+\mathrm{b}+\mathrm{c}$

\section{c. Analisis Komponen Utama}

Interaksi tumbuhan sagu dengan komponen abiotis, didekati dengan menggunakan analisis komponen utama (Principal Component Analysis/PCA) (Supranto, 2004).

\section{HASIL DAN PEMBAHASAN}

\section{A. Struktur Populasi}

Secara umum struktur populasi tumbuhan sagu di Pulau Seram mengikuti pola pertumbuhan muda yaitu populasi dengan jumlah individu paling banyak terdapat pada fase semai, berkurang secara drastis pada fase berikutnya (Gambar 2). Dalam populasi tersebut jumlah individu fase semai yang berhasil tumbuh ke fase pertumbuhan berikutnya hanya sebesar $15,34 \%$. Hal ini menunjukkan bahwa terjadi kematian individu fase semai, gagal tumbuh ke fase berikutnya mencapai $84,66 \%$. Tingginya tingkat kematian ini dapat disebabkan karena : (1) sifat pertumbuhan anakan sagu, sebagian tunas anakan yang muncul dari pangkal batang tidak bersentuhan dengan tanah, (2) terjadi persaingan di antara masing-masing individu dalam rumpunnya. Persaingan yang dimaksud berkaitan dengan komponen di atas permukaan tanah seperti udara, cahaya, ruang, dan komponen di bawah tanah seperti air, oksigen, dan unsur hara. Hasil pengukuran intensitas cahaya surya di dekat rumpun sagu hanya sekitar 12,33\% (206,53 lux, 
ruang terbuka 1675,29 lux). Rendahnya intensitas ini karena terdapat hambatan oleh tajuk rumpun sagu itu sendiri, (3) rentan terhadap $\mathrm{pH}$ rendah, tunas anakan yang masih muda memiliki daya adaptasi yang rendah terhadap kondisi lahan tergenang (tereduksi). Hasil pengukuran kemasam- an tanah menunjuk-kan bahwa $\mathrm{pH}$ tanah dapat mencapai 4,31 (pH KCl), dan (4) mengalami keracunan karena kandungan $\mathrm{Fe}(3,08)$ dan $\mathrm{Al}$ $(4,99)$ tanah, nilai kekurangan $\mathrm{Fe}$ dan $\mathrm{Al}$ tersebut termasuk kategori sangat tinggi berdasarkan kriteria (Balai Penelitian Tanah, 2005).

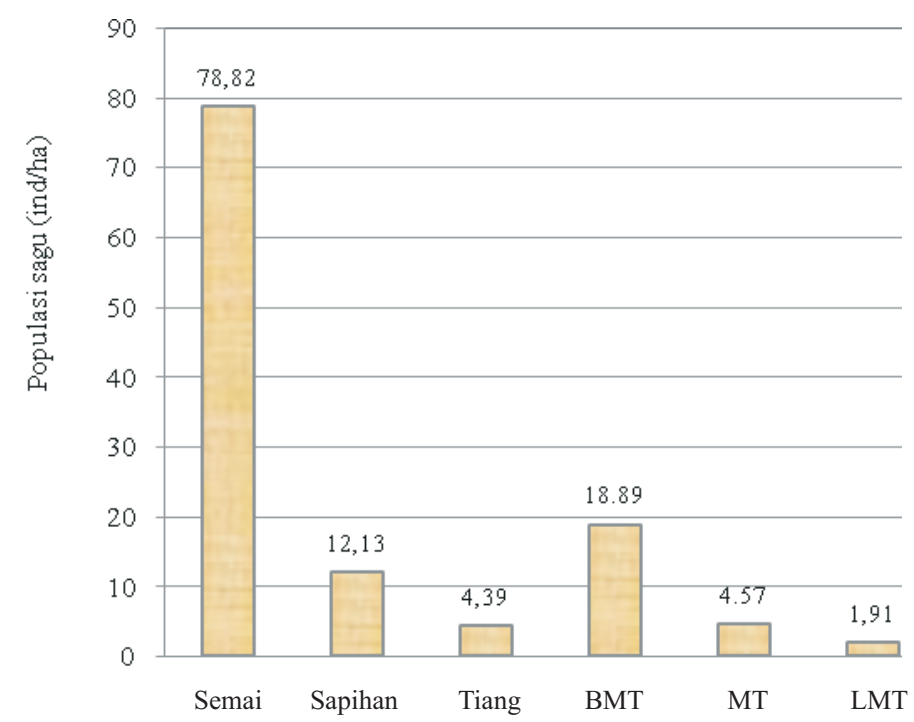

Fase pertumbuhan (Growth stage)

$\begin{aligned} & \text { Keterangan (Remarks): } \text { BMT }=\text { Belum Masak Tebang (Immature Trunks), } \\ & \text { MT }=\text { Masak Tebang (Mature Trees }- \text { Harvestable), } \\ & \text { LMT }=\text { Lewat Masak Tebang (Mature Trees } \text { Not Harvestable) }\end{aligned}$

Gambar(Figure) 2. Struktur populasi sagu di Pulau Seram (Population structure of sago palm at the Seram Island).

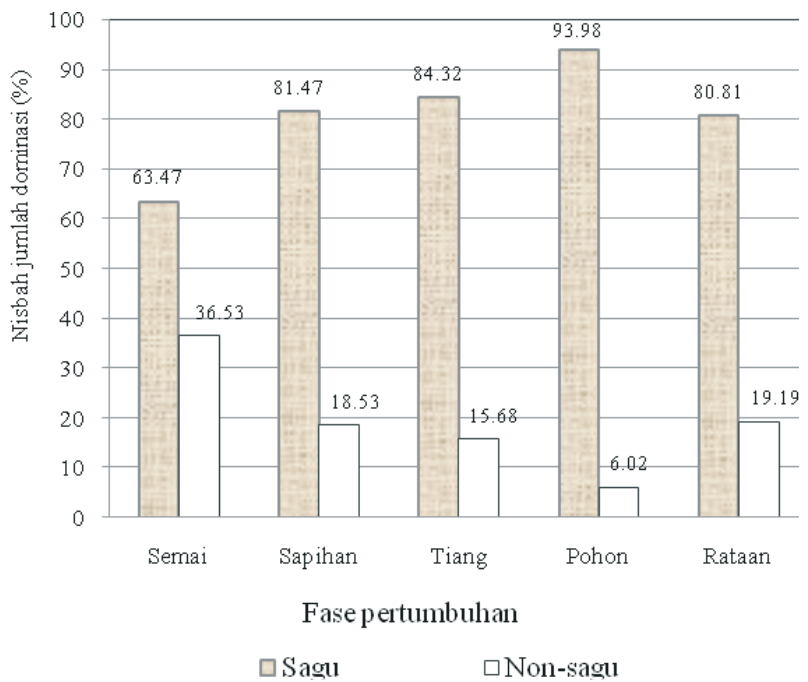

Gambar(Figure) 3. Perbandingan NJD sagu dan non-sagu di plot penelitian (SDR camparison of sago palm and non sago palm at the research plot). 


\section{B. Kelimpahan Spesies}

Hasil perhitungan jumlah populasi rumpun sagu dan nisbah jumlah dominasi (NJD) dalam komunitas sagu menunjukkan bahwa spesies sagu merupakan jenis vegetasi yang menguasai sebagian besar areal lahan di plot penelitian. Kondisi tersebut dapat terlihat dengan bertambahnya fase pertumbuhan, maka dominasi spesies sagu juga meningkat (Gambar 3). Fenomena seperti ini merupakan gambaran umum yang sering dijumpai pada tipe vegetasi yang mengarah kepada kondisi klimaks dan stabil. Mueller \& Ellenberg (1974 dalam Setiadi 2005) mengemukakan bahwa komposisi bervegetasi alami yang telah terbentuk dalam jangka panjang akan memperlihatkan fisiognomi, fenologi, dan daya regenerasi yang lambat dan cenderung mantap, sehingga dinamika floristik komunitas hutan tidak terlalu nyata dan menyolok. Jika kondisi ini terjadi maka regenerasi spesies seakan-akan tidak tampak, akibatnya jarang dijumpai spesies tertentu yang kemudian muncul dominan, karena semua spesies telah beradaptasi dalam jangka waktu lama. Berdasarkan penelitian tersebut jumlah individu masing-masing spesies sagu, diperoleh hasil ditemukan bahwa sagu tuni memiliki jumlah individu paling banyak $(99,93$ ind/ha) dan NJD paling tinggi (43,3\%). Jumlah tersebut menunjukkan bahwa sagu tuni merupakan spesies tumbuhan yang memiliki kerapatan, dominasi, dan frekwensi yang melampaui spesies yang lain dengan penguasaan habitat mencapai $43,3 \%$.

\section{Habitat dan Adaptasi Tumbuhan Sagu}

Secara umum tipe habitat sagu di Pulau Seram dapat dipisahkan menjadi dua kategori yaitu (1) habitat lahan kering dan (2) habitat lahan tergenang, berupa rawa-rawa yang tergenang secara temporer maupun permanen. Dua tipe habitat itu dapat dipisahkan lebih lanjut menjadi empat tipe yaitu : (1) habitat tergenang temporer air payau yaitu tipe habitat yang dicirikan oleh adanya pasangsurut, (2) habitat tergenang temporer oleh air tawar yaitu tipe habitat dimana genangannya sangat ditentukan oleh ada-tidaknya hujan, (3) habitat tergenang permanen, yaitu tipe habitat yang mengalami genangan pada periode waktu relatif cukup lama, biasanya lebih dari satu bulan, dan (4) habitat lahan kering, artinya kondisi habitatnya tidak pernah tergenang. Kondisi tersebut ditemukan pada setiap sempel dan masih perlu riset lebih lanjut untuk memetakan luasnya.

Hasil penelitian menunjukkan bahwa tidak semua jenis sagu dapat tumbuh pada setiap tipe habitat. Jenis sagu yang dapat tumbuh dan berkembang pada semua tipe habitat adalah jenis sagu tuni, makanaro, dan sylvestre (Tabel 1). Dua jenis sagu yang lain yakni rotang dan molat tumbuh pada habitat terbatas. Jenis sagu rotang hanya ditemukan tumbuh pada tipe habitat lahan kering (TTG), sedangkan jenis sagu molat ditemukan tumbuh pada dua tipe habitat yaitu tergenang temporer air tawar (T2AT) dan tergenang permanen (TPN).

Apabila interaksi tumbuhan sagu dengan tipe habitat ini dijadikan acuan untuk menjelaskan kemampuan adaptasinya, maka

Tabel (Table) 1. Populasi rumpun sagu pada tipe habitat berbeda di Pulau Seram (Clumps population of sago palm of the habitat type at the Seram Island))

\begin{tabular}{|c|c|c|c|c|c|c|c|c|c|c|c|}
\hline \multirow{3}{*}{ No. } & \multirow{3}{*}{$\begin{array}{l}\text { Jenis sagu } \\
\text { (Sago } \\
\text { species) }\end{array}$} & \multicolumn{8}{|c|}{ Tipe Habitat (Habitat Type) } & \multirow{2}{*}{\multicolumn{2}{|c|}{$\begin{array}{l}\text { Rataan } \\
\text { (Average) }\end{array}$}} \\
\hline & & \multicolumn{2}{|c|}{ TTG } & \multicolumn{2}{|c|}{ T2AT } & \multicolumn{2}{|c|}{ T2AP } & \multicolumn{2}{|c|}{ TPN } & & \\
\hline & & ind/ha & $\%$ & ind/ha & $\%$ & ind/ha & $\%$ & ind/ha & $\%$ & ind/ha & $\%$ \\
\hline 1. & Tuni & 103,26 & 58,86 & 124,33 & 50,14 & 62,08 & 64,22 & 61,20 & 37,31 & 87,72 & 52,64 \\
\hline 2. & Makanaro & 28,37 & 15,80 & 26,01 & 10,49 & 20,00 & 20,69 & 36,04 & 21,97 & 27,60 & 17,24 \\
\hline 3. & Sylvestre & 37,95 & 22,87 & 85,10 & 34,32 & 14,58 & 15,09 & 11,58 & 7,06 & 37,30 & 19,83 \\
\hline 4. & Rotang & 4,27 & 2,47 & 0,00 & 0,00 & 0,00 & 0,00 & 0,00 & 0,00 & 1,07 & 0,62 \\
\hline 5. & Molat & 0,00 & 0,00 & 12,50 & 5,04 & 0,00 & 0,00 & 55,19 & 33,65 & 16,92 & 9,67 \\
\hline & Jumlah & 173,85 & 100,0 & 274,94 & 100,0 & 96,66 & 100,0 & 164,01 & 100,0 & 170,61 & 100,0 \\
\hline
\end{tabular}

Keterangan $($ Remarks) : TTG = tidak tergenang (dry land), $\mathrm{T} 2 \mathrm{AT}=$ tergenang temporer air tawar (temporery inundated fresh water swamp), $\mathrm{T} 2 \mathrm{AP}=$ tergenang temporer air payau (temporery inundated brackish water swamp), TPN = tergenang permanen (permanent inundated fresh weter swamp), ind = individu (individual). 
dapat dikatakan bahwa jenis sagu tuni memiliki kemampuan adaptasi yang luas (eury tolerance). Hal tersebut ditunjukkan dari jumlah rumpun dan jumlah populasi semua fase pertumbuhan yang lebih tinggi dibandingkan dengan jenis sagu yang lain. Jenis sagu makanaro dan sylvestre tumbuh pada semua tipe habitat, namun memiliki populasi yang rendah. Molat ditemukan pada habitat T2AT dan TPN. Dengan demikian dapat dikatakan bahwa tiga jenis sagu tersebut memiliki daya adaptasi sedang (meso tolerance). Sagu rotang merupakan jenis sagu yang memiliki daya adaptasi paling terbatas karena hanya tumbuh pada habitat lahan kering (steno tolerance).

\section{Mekanisme Adaptasi Sagu}

Sebagian besar sagu tumbuh pada lahan tergenang, baik yang sifatnya temporer maupun permanen, dan tiga (3) dari empat (4) tipe plot penelitian termasuk kategori tergenang. Kondisi plot yang senantiasa tergenang cenderung merupakan kondisi tanah masam. Berdasarkan hasil penelitian $\mathrm{pH}$ tanah menunjukkan kisaran $\mathrm{pH}$ tanah $\left(\mathrm{pH} \mathrm{H}_{2} \mathrm{O}\right)$ 4,47 - 5,63 dan $\mathrm{pH} \mathrm{KCl} \mathrm{4,31.}$ Tanah-tanah masam dengan kandungan logam tinggi seperti $\mathrm{Fe}$ dan $\mathrm{Al}$ dapat berpengaruh buruk terhadap kehidupan perakaran. Syekhfani (1997) mengemukakan bahwa logam memiliki kemampuan untuk melisis air sehingga $\mathrm{pH}$ tanah dapat semakin masam. Ketika $\mathrm{pH}$ rendah, $\mathrm{Fe}$ dan Al akan larut sehingga konsentrasinya meningkat dan dapat bersifat meracun (toxic) (Brady 1990). Habitat tergenang identik dengan kondisi tereduksi, artinya keadaan dimana terjadi keterbatasan oksigen di dalam tanah. Levitt (1980) menyebutnya sebagai cekaman defisit oksigen. Dalam kaitan dengan kondisi yang tereduksi ini, maka adaptasi sagu ditunjukkan melalui sistem perakarannya yang mengalami modifikasi arah pertumbuhan (Gambar 4). Pada habitat tergenang biasanya muncul akar berukuran kecil dalam jumlah banyak dengan arah pertumbuhan menuju permukaan air sehingga terjadi kontak langsung dengan udara bebas. Mekanisme perubahan ini agar penyerapan oksigen oleh perakaran dapat berlangsung dengan baik. Berbeda dengan jenis lain, maka pada kondisi lahan dengan aerase jelek, tumbuhan melakukan mekanisme adaptasi morfologi dengan membentuk sistem perakaran dangkal (Daubenmire, 1974).

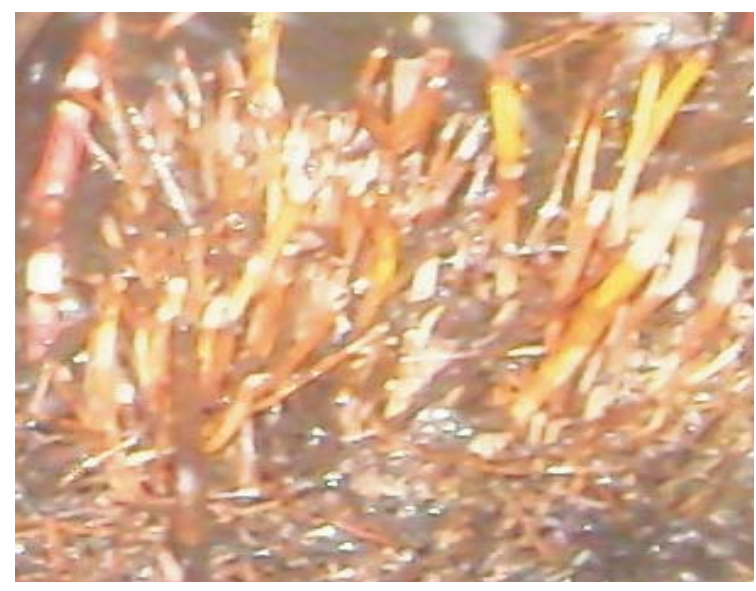

Gambar (Figure) 4. Modifikasi arah pertumbuhan akar sagu pada kondisi tergenang (Roots growth modification of sago palm af the swamp condition)

\section{E. Interaksi dengan Faktor Lingkungan}

\section{Komponen Biologis}

Hasil analisis asosiasi interspesifik menunjukkan bahwa secara simultan (keseluruhan) terjadi asosiasi antar spesies dalam komunitas sagu alami di Pulau Seram dengan nilai VR sebesar 0,83 . Nilai $\mathrm{VR}<1$ mengandung makna bahwa asosiasi antara spesies bersifat negatif. Hasil analisis asosiasi spesies berpasangan menunjukkan bahwa terdapat asosiasi diantara spesies sagu dan antara sagu dengan non sagu dengan nilai chi-square berkisar dari 4,35-21,03 dengan indeks Jaccard rata-rata 0,14 (termasuk kategori rendah) (Tabel 2).

Asosiasi antar spesies yang bersifat negatif menunjukkan bahwa terjadi perebutan dalam penggunaan sumberdaya. Dengan meningkatnya jumlah individu yang satu akan menekan pertumbuhan individu spesies lain (Soegianto, 1994). Interaksi yang bersifat negatif meberikan petunjuk pula bahwa tidak terdapat toleransi untuk hidup secara bersama atau tidak ada hubungan timbal balik yang saling menguntungkan, terutama dalam pembagian ruang hidup. Barbour et al. (1999 dalam Kurniawan et al. 2008) mengemukakan bahwa asosiasi yang bersifat negatif memberikan petunjuk bahwa setiap tumbuhan dalam suatu komunitas terjadi saling memberi tempat hidup pada suatu area habitat yang sama. Menurut Krivan \& Sirot (2002) dikemukakan bahwa dalam asosiasi interspesifik dapat memunculkan kompetisi interspesifik. Pada kondisi dimana asosiasi bersifat negatif ekstrim, suatu spesies dapat muncul sebagai kompetitor yang mendominasi spesies lain. 
Tabel(Table)2. Chi-square untuk pengujian asosiasi interspesifik spesies berpasangan penyusun utama komunitas sagu pada plot penelitian di Pulau Seram (Chi-square for interspecific association test to pair dominant species in the sago palm community atresearch plot the Seram Island)

\begin{tabular}{|c|c|c|c|c|}
\hline No. & Nama spesies (Species name) & Chi-square $\left(\mathrm{X}^{2}\right)$ & $\mid \begin{array}{c}\text { Tipe Asosiasi } \\
\text { (Association type) }\end{array}$ & $\begin{array}{l}\text { Indeks Jaccard } \\
\text { (Jaccard index) }\end{array}$ \\
\hline 1. & M. rumphii Mart subvar tuni (Becc) & & & \\
\hline 1.1 & M. rumphii subvar makanaro & $6,53^{*}$ & Negatif & 0,43 \\
\hline 1.2 & M. rumphii var sylvestre & $5,12 *$ & Negatif & 0,47 \\
\hline 1.3 & M. sagu var molat & $16,74 *$ & Negatif & 0,16 \\
\hline 1.4 & Pandanus furcatus Roxb. & $6,76^{*}$ & Negatif & 0,06 \\
\hline 1.5 & Homalomena sp. & $9,28 *$ & Negatif & 0,15 \\
\hline 1.6 & Nephrolepis sp. & $21,03 *$ & Negatif & 0,05 \\
\hline 2. & M. rumphii Mart subvar makanaro (Becc) & & & \\
\hline 2.1 & M. rumphii var sylvestre & $20,73 *$ & Negatif & 0,15 \\
\hline 2.2 & M. sagu var molat & $5,69 *$ & Negatif & 0,20 \\
\hline 2.3 & Homalomena sp. & $4,35^{*}$ & Negatif & 0,08 \\
\hline 2.4 & Nephrolepis sp. & $4,76^{*}$ & Negatif & 0,04 \\
\hline 3. & M. rumphii Mart var sylvestre (Becc) & & & \\
\hline 3.1 & M. sagu var molat & $5,31 *$ & Negatif & 0,14 \\
\hline 3.2 & Homalomena sp. & $4,45^{*}$ & Negatif & 0,04 \\
\hline 3.3 & Nephrolepis sp. & $4,96^{*}$ & Negatif & 0,04 \\
\hline 4. & M. sagu Rottb var molat (Becc) & & & \\
\hline 4.1 & Pandanus furcatus Roxb. & $4,56^{*}$ & Negatif & 0,10 \\
\hline 4.2 & Nephrolepis sp. & $4,48^{*}$ & Negatif & 0,02 \\
\hline
\end{tabular}

Keterangan (Remarks): * signifikan pada taraf $\alpha 0,05$ (significant of the $\alpha 0,05$ )

\section{Komponen Abiotis}

a. Variabel Iklim

Hasil analisis komponen utama (Principal Component Analysis/PCA) untuk menjelaskan interaksi variabel iklim menggunakan loading plot menunjukkan bahwa terdapat korelasi positif antara variabel sinaran surya lokal dan mikro (Gambar 5). Hal ini ditunjukkan dengan sudut lancip yang dibentuk garis loading plot kedua variabel tersebut (Setiadi, 1998). Korelasi yang bersifat positif mengandung pengertian bahwa apabila sinaran surya lokal meningkat, maka diikuti dengan peningkatan sinaran surya mikro. Korelasi yang sama terjadi pula antara variabel sinaran surya dengan temperatur mikro, sinaran surya lokal dan curah hujan dengan kelembaban mikro. Sedangkan variabel temperatur mikro, sinaran surya lokal, dan sinaran surya mikro memiliki korelasi negatif dengan curah hujan (ditunjukkan oleh sudut tumpul garis loading plotnya). Hal ini berarti bahwa apabila curah hujan bertambah, maka sinaran surya (lokal \& mikro), dan temperatur mikro akan menurun. Korelasi negatif terjadi pula antara variabel temperatur mikro dengan kelembaban mikro.

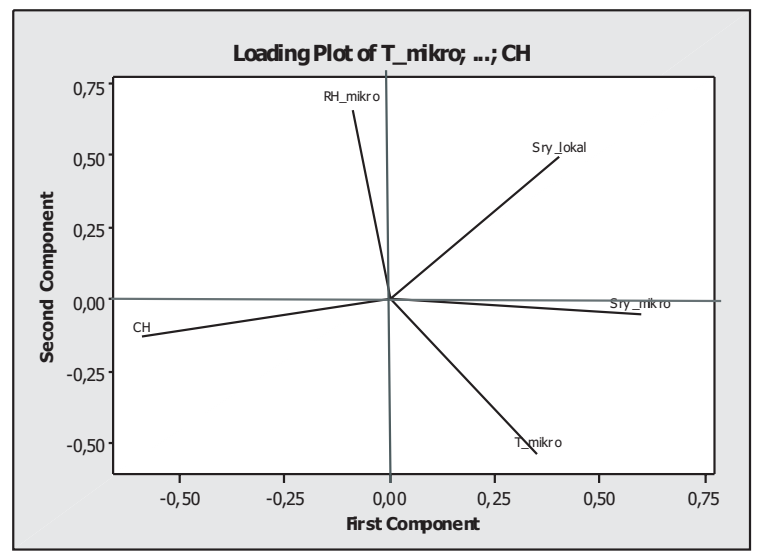

Gambar (Figure) 5. Diagram loading plot korelasi variabel iklim habitat sagu di Pulau Seram (Loading plot diagram of climate variable correlation of the sago palm habitat at the Seram Island)

Dengan mempertimbangkan akar ciri (eigenvalues) dan vektor ciri (eigenvector) terbesar, maka dapat ditentukan besarnya kontribusi relatif masing-masing variabel (Dewi, 2005 \& Marzuki, 2007). Dalam konteks ini besarnya kontribusi terhadap pertumbuhan sagu (PS). Hasil perhitungan menunjukkan bahwa jumlah kontribusi faktor iklim terhadap PS di Pulau Seram sebesar 3,38\%. Model indeksnya sebagai berikut : 
$\operatorname{PS}_{\text {(F-iklim) }}=\left(0,78_{\text {T-mikro }}\right)+\left(1,47_{\text {RH-mikro }}\right)+\left(1,10_{\text {Sry-lokal }}\right)$ $+\left(1,66_{\text {Sry-mikro }}\right)-\left(1,63_{\text {C-hujan }}\right)$

dimana : $\mathrm{PS}=$ pertumbuhan sagu terkait dengan faktor iklim; T-mikro = temperatur mikro; RH-mikro = kelembaban mikro; Syr-lokal = sinaran surya lokal; Srymikro $=$ sinaran surya mikro; C-hujan = curan hujan.

Pada model indeks PS di atas, tampak bahwa pertumbuhan sagu di Pulau Seram sangat ditentukan oleh variabel intensitas cahaya surya mikro. Fakta ini semakin memperkuat argumen bahwa kematian tunas anakan sagu antara lain dipengaruhi oleh banyaknya intensitas cahaya surya yang masuk sampai ke bagian bawah tajuk rumpun sagu. Banyak tunas anakan sagu mengalami kematian karena terjadi kompetisi yang kuat diantara individu setiap rumpun dalam mendapatkan sinaran surya. Cahaya surya yang masuk sampai dekat rumpun sagu hanya mencapai $12,40 \%$.

\section{b. Interaksi dengan Variabel Tanah}

Hasil analisis PCA faktor tanah menunjukkan bahwa variabel $\mathrm{C}$-organik berkorelasi positif dengan $\mathrm{pH}$, kalsium, KTK, magnesium, dan kalium (Gambar 6). Korelasi positif terjadi pula antara KTK dengan kalsium, magnesium, dan kalium. Partikel liat berkorelasi positif dengan bulk density (BD). Hal ini berarti bahwa jika terjadi peningkatan suatu variabel, maka akan diikuti dengan variabel yang lain. Sedangkan $\mathrm{pH}$ berkorelasi negatif dengan $\mathrm{Fe}$, artinya apabila $\mathrm{Fe}$ meningkat, maka $\mathrm{pH}$ akan berkurang (semakin masam).

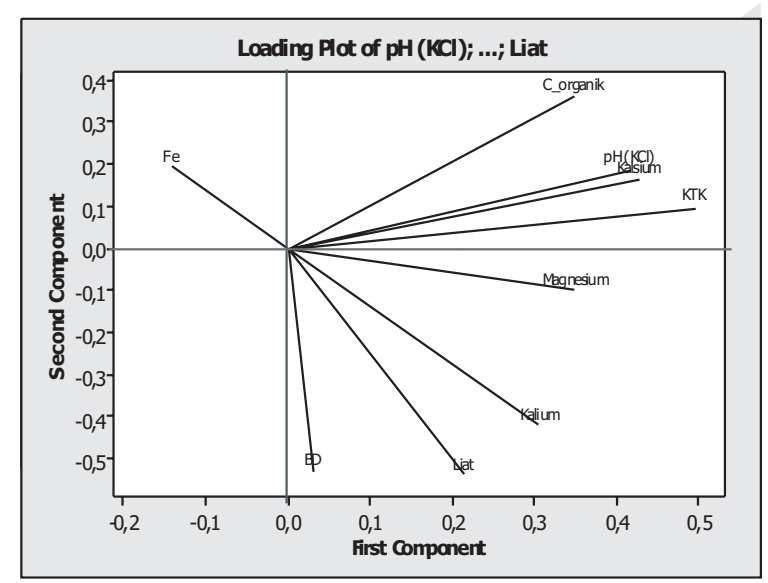

Gambar(Figure) 6. Diagram loading plot korelasi variabel tanah habitat sagu di Pulau Seram (Loading plot diagram of soil variable correlation of the sago palm habitat at the Seram Island).
Dengan mempertimbangkan eigenvalues dan nilai eigenvector terbesar, maka dapat ditentukan besarnya kontribusi relatif masingmasing variabel tanah terhadap pertumbuhan sagu. Hasil perhitungan menunjukkan bahwa jumlah kontribusi faktor tanah terhadap PS di Pulau Seram sebesar 10,15\%. Variabel tanah yang memiliki kontribusi tertinggi adalah KTK $(1,90 \%)$. Model indeksnya sbb :

$\operatorname{PS}_{(\text {- -tanah) }}=\left(1,60_{\text {рH-KC }}\right)+\left(0,83_{\text {C-org }}\right)+\left(1,90_{\text {KTK }}\right)+$ $\left(1,17_{\mathrm{K}}\right)+\left(1,64_{\mathrm{Ca}}\right)+\left(0,85_{\mathrm{Mg}}\right)+\left(1,07_{\mathrm{Fe}}\right)+\left(0,27_{\mathrm{BD}}\right)+$ $\left(0,82_{\text {Liat }}\right)$

dimana : $\left.\operatorname{PS}_{(\mathrm{F}-\text { tanah }}\right)=$ pertumbuhan sagu terkait dengan faktor tanah; $\mathrm{pH}-\mathrm{KCl}=$ kemasaman tanah potensial; $\mathrm{C}$-org $=$ karbon organik; KTK = kapasitas tukar kation; $\mathrm{K}=$ Kalium; $\mathrm{Ca}=$ Kalsium; $\mathrm{Mg}=$ Magnesium; $\mathrm{Fe}=$ Ferrum; $\mathrm{BD}=$ bulk density $;$ Liat $=$ partikel liat .

Pada model di atas, tampak bahwa pertumbuhan sagu di Pulau Seram dalam kaitannya dengan sifat tanah sangat ditentukan oleh kapasitas tukar kation (KTK). Hal ini berarti bahwa sagu menghendaki tanah dengan kesuburan yang memadai. Argumen ini dikemukakan karena KTK merupakan parameter tanah yang berkaitan dengan kesuburan tanah (Hardjowigeno 1992). Tanah dengan KTK tinggi menunjukkan bahwa tanah tersebut subur, dan sebaliknya apabila KTK rendah termasuk kurang subur.

\section{c. Interaksi dengan Variabel Kualitas Air Rawa}

Hasil analisis PCA kualitas air rawa menunjukkan bahwa $\mathrm{pH}$ air memiliki korelasi positif dengan kalium, kalsium, dan magnesium (Gambar 7). Korelasi yang bersifat positif ini mengandung pengertian bahwa dengan makin bertambah kandungan kalium, kalsium, dan magnesium, maka $\mathrm{pH}$ air akan meningkat. Kalium, kalsium, dan magnesium merupakan kation basa yang memainkan peranan dalam meningkatkan $\mathrm{pH}$. Selain itu kation-kation basa yang meningkat, dengan sendirinya akan meningkatkan kadar salinitas.

Dengan mempertimbangkan eigenvalues dan nilai eigenvector terbesar, maka ditentukan besarnya kontribusi relatif variabel kualitas air rawa terhadap PS. Hasil perhitungan menunjukkan bahwa jumlah kontribusi faktor kualitas air rawa terhadap PS di plot penelitian sebesar $10,15 \%$. Variabel kualitas air rawa yang memiliki 
kontribusi tertinggi adalah kalsium (1,73\%). Model indeks PS terkait dengan peran faktor kualitas air rawa di Pulau Seram sebagai berikut :

$\operatorname{PS}_{(\mathrm{F}-\mathrm{KAR})}=\left(1,61_{\mathrm{pH}}\right)+\left(1,18_{\mathrm{K}}\right)+\left(1,73_{\mathrm{Ca}}\right)+\left(1,10_{\mathrm{Mg}}+\right.$ $\left(0,50_{\mathrm{NO} 3}\right)+\left(0,14_{\text {Salinitas }}\right)$

dimana: $\left.\mathrm{PS}_{(\mathrm{F}-\mathrm{KAR}}\right)=$ pertumbuhan sagu terkait dengan faktor kualitas air rawa; $\mathrm{pH}=$ kemasaman air; $\mathrm{K}=$ Kalium; $\mathrm{Ca}=$ Kalsium; $\mathrm{Mg}=$ Magnesium; $\mathrm{NO}_{3}=$ Nitrat

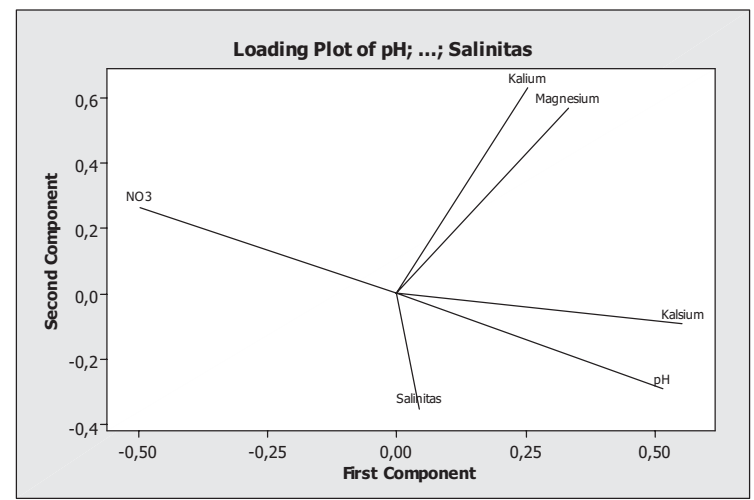

Gambar(Figure) 7. Diagram loading plot korelasi variabel kualitas air rawa habitat sagu di Pulau Seram (Loading plot diagram of water swamp quality variable correlation of the sago palm habitat at the Seram Island)

Pada model indeks di atas, tampak bahwa pertumbuhan sagu di Pulau Seram dalam kaitannya dengan kualitas air rawa sangat ditentukan oleh kandungan kalsium. Hal ini berarti bahwa untuk pertumbuhan sagu diperlukan kalsium yang memadai. Kalsium merupakan unsur hara esensial makro, artinya diperlukan oleh tumbuhan dalam jumlah yang relatif banyak. Kalsium juga merupakan kation basa yang berperan dalam memperbaiki kemasaman air.

\section{d. Potensi Populasi dan Produksi Pati Sagu di P. Seram}

Di Pulau Seram Maluku terdapat potensi luas areal sagu sekitar 18.239 ha. Pada luas areal tersebut tumbuh dan berkembang sekitar 3,22 juta rumpun sagu, terdiri dari sagu fase semai 6,14 juta individu, sapihan 1,59 individu, tiang 0,55 juta individu, pohon 1,47 juta individu, pohon masak tebang 0,35 juta individu, dan pohon lewat masak tebang 0,12 juta individu (Tabel 3). Atas dasar jumlah individu yang dimiliki, dapat dikatakan bahwa sagu tuni merupakan jenis sagu yang sangat potensial karena memiliki jumlah individu yang jauh lebih banyak dibandingkan dengan jenis sagu yang lain (1,714 juta rumpun).

Hasil perhitungan potensi produksi pati sagu basah di plot penelitian wilayah Pulau Seram diperoleh bahwa jenis sagu tuni dan sylvestre memiliki potensi produksi paling tinggi. Berdasarkan tipe habitat, pada habitat tidak tergenang (lahan kering) potensi produksi sagu basah tuni rata-rata mencapai 685,50 $\mathrm{kg} /$ batang, sylvestre 726,22 kg/batang (Tabel 4). Potensi produksi kedua jenis sagu ini hampir sama pada semua tipe habitat. Pada tabel 4 tampak bahwa tipe habitat berperan dalam mempengaruhi produksi pati sagu. Pada tipe habitat TTG dan T2AT produksi pati sagu hampir dua kali lebih tinggi dibandingkan dengan tipe habitat T2AP dan TPN.

Tabel (Table) 3. Potensi populasi tumbuhan sagu di P. Seram (Population potential of sago palm at the Seram Island)

\begin{tabular}{|c|c|c|c|c|c|c|c|}
\hline \multirow[b]{2}{*}{$\begin{array}{l}\text { Jenis Sagu } \\
\text { (Sago } \\
\text { Species) }\end{array}$} & \multirow{2}{*}{$\begin{array}{l}\text { Jumlah } \\
\text { Rumpun } \\
\text { (Numbers } \\
\text { of Clump) }\end{array}$} & \multicolumn{6}{|c|}{ Fase Pertumbuhan } \\
\hline & & $\begin{array}{c}\text { Semai } \\
\text { (Seedling) }\end{array}$ & $\begin{array}{l}\text { Sapihan } \\
\text { (Sapling) }\end{array}$ & $\begin{array}{l}\text { Tiang } \\
\text { (Pole) }\end{array}$ & $\begin{array}{l}\text { Pohon } \\
\text { (trees) }\end{array}$ & $\begin{array}{l}\text { Phn. Masak } \\
\text { Tebang } \\
\text { (Mature trees } \\
\text { Harvestabe) }\end{array}$ & $\begin{array}{c}\text { Phn. Lewat } \\
\text { Masak Tebang } \\
\text { (Mature trees } \\
\text { Non Harvestabe) }\end{array}$ \\
\hline & & & & x 100 & & & \\
\hline Tuni & $1.714,3$ & $2.991,9$ & 775,8 & 279,3 & 678,3 & 114,8 & 12,8 \\
\hline Makanaro & 543,8 & $1.025,6$ & 277,6 & 95,9 & 276,2 & 104,5 & 58,6 \\
\hline Sylvestre & 629,8 & $1.745,8$ & 378,7 & 118,4 & 331,0 & 67,0 & 9,6 \\
\hline Rotang & 27,5 & 57,3 & 13,7 & 3,2 & 20,1 & 0,0 & 0,0 \\
\hline Molat & 304,8 & 315,2 & 142,7 & 55,3 & 162,8 & 61,8 & 37,1 \\
\hline Jumlah & $3.220,2$ & $6.135,8$ & $1.588,6$ & 552,1 & $1.468,2$ & 348,0 & 118,1 \\
\hline
\end{tabular}

Keterangan (Remarks) : Data primer tahun 2009 (Primery data in 2009 year), $\mathrm{Phn}=$ pohon (trees), ind =individu (individual). 
Tabel (Table) 4. Potensi produksi pati sagu pada tipe habitat berbeda di P. Seram (Yield potential of sago palm starch of the habitat type at the Seram Island)

\begin{tabular}{|l|l|cccc|c|}
\hline \multirow{2}{*}{ No. } & \multirow{2}{*}{$\begin{array}{c}\text { Jenis Sagu } \\
\text { (Sago Species) }\end{array}$} & \multicolumn{4}{|c|}{ Tipe Habitat (Habitat Types) } & \multirow{2}{*}{$\begin{array}{c}\text { Rataan } \\
\text { (Average) }\end{array}$} \\
\cline { 3 - 6 } & & TTG & T2AT & T2AP & TPN & \\
\hline 1. & Tuni & 685,50 & 721,50 & 479,17 & 378,00 & 566,04 \\
2. & Makanaro & 324,50 & 287,11 & 186,00 & 183,22 & 245,21 \\
3. & Sylvestre & 726,22 & 708,00 & 460,50 & 348,00 & 560,68 \\
4. & Molat & - & 348,44 & - & 126,00 & 237,22 \\
\hline & Rataan & 578,74 & 516,26 & 353,06 & 258,81 & 393,13 \\
\hline
\end{tabular}

Keterangan (Remarks): TTG = tidak tergenang (dryland), T2AT= tergenang temporer air tawar (temporery inundated fresh water swamp), T2AP = tergenang temporer air payau (temporery inundated brackish water swamp), TPN= tergenang permanen (permanent inundated fresh weter swamp).

\section{KESIMPULAN DAN SARAN}

\section{A. Kesimpulan}

1. Struktur populasi sagu di plot penelitian wilayah Pulau Seram mengikuti pola pertumbuhan muda, didominasi oleh fase semai dengan tingkat kegagalan untuk tumbuh ke fase berikutnya sangat tinggi mencapai $85 \%$.

2. Dalam komunitas sagu alami di plot penelitian wilayah Pulau Seram, spesies sagu telah berkembang mendominasi sebagian besar habitatnya, tumbuh dan berkembang mengarah kepada kondisi vegetasi yang bersifat klimaks dan stabil. Dalam komunitas tersebut terjadi asosiasi interspesifik bersifat negatif, baik secara kolektif maupun antara spesies berpasangan, dengan tingkat asosiasi secara umum rendah $(\mathrm{JI}<0,2)$.

3. Sagu tuni merupakan jenis yang memiliki daya adaptasi luas (eury tolerance), sedangkan rotang merupakan jenis yang memiliki daya adaptasi sempit (steno tolerance). Tiga jenis sagu yang lain yaitu makanaro, sylvestre, dan molat dikategorikan sebagai jenis sagu yang memiliki daya adaptasi sedang (meso tolerance).

4. Terdapat interaksi antara tumbuhan sagu dengan faktor lingkungan (iklim, tanah, kualitas air rawa, dan vegetasi non sagu). Variabel iklim, tanah, dan kualitas air rawa yang paling berperan terhadap pertumbuhan sagu di Pulau Seram masing-masing adalah intensitas cahaya surya mikro, kapasistas tukar kation, dan kandungan kalsium air.

5. Sagu tuni dan sylvestre merupakan jenis sagu yang memiliki kapasitas produksi pati sagu yang cukup tinggi, masing-masing mencapai 566,04 dan 560,68 kg/batang, sedangkan kapasistas produksi sagu basah jenis sagu makanaro dan molat masing-masing sekitar 245,21 dan $237,22 \mathrm{~kg} /$ batang.

\section{B. Saran}

1. Upaya diversifikasi pangan sumber karbohidrat dari jenis sagu bagi masyarakat di pedesaan Maluku dan Papua, maupun pemenuhan kebutuhan berbagai industri (makanan, minuman, bioetanol atau industri lainnya), dapat dilakukan dengan mengembangkan jenis sagu tuni serta sagu sylvestre baik pada tipe habitat lahan kering maupun tipe lahan tergenang temporer air tawar.

2. Upaya peningkatan produksi pati sagu di habitat alam dapat dilakukan dengan penyatuan pola pertumbuhan individu dalam rumpun yang stabil melalui upaya sortasi anakan dan pengaturan jarak tumbuh antar individu rumpun.

\section{DAFTAR PUSTAKA}

[BPT] Balai Penelitian Tanah. 2005. Petunjuk Teknis Analisis Kimia Tanah, Tanaman, Air, dan Pupuk. Badan Penelitian dan Pengembangan Pertanian, Departemen Pertanian. Bogor.

Brady, N.C. 1990. The Nature and Properties of Soils. MacMillian Publishing Company. New York. 
Cox, G.W. 2002. General Ecology, Laboratory Manual. Eigth edition. McGraw Hill. New York.

Daubenmire, R.F. 1974. Plant and Environment, a Textbook of Autecology. Third edition. John Wiley \& Sons. New York

Flach, M. 1997. Promoting the Conservation and Use of Underutilized and Neglected Crops. Sago Palm, Metroxylon sagu Rottb. Wageningen Agriculture University, Netherlands. International Plant Genetic Resources Institute, Rome. pp 76. http://www.ipgri.cgiar.org/Publications/ pdf/238.pdf. Diakses tanggal 11 Agustus 2008 .

Hardjowigeno, S. 1992. Ilmu Tanah. Melton Putra. Jakarta

Krivan, V., and E. Sirot. 2002. Habitat Selection by to Competing Species in a Two-Habitat Environment. J The American Naturalist 160 (2) 214-234.

Kurniawan, A., K.E.Undaharta Ni, dan I Made R. Pendit. 2008. Asosiasi Jenis-Jenis Pohon Dominan di Hutan Dataran Rendah Cagar Alam Tangkoko, Bitung, Sulawesi Utara. J Biodiversitas 8 (3) : 199-203.

Kusmana, C. 1997. Metode Survey Vegetasi. PT. Penerbit Institut Pertanian Bogor. Bogor.

Levitt, J. 1980. Responses of Plant to Environmental Stresses. Second edition. Academic Press. New York

Louhenapessy, J.E. 2006. Potensi dan pengelolaan sagu di Maluku. Makalah disampaikan pada lokakarya sagu dengan tema sagu dalam revitalisasi pertanian Maluku. Ambon 29-31 Mei 2006.

Ludwig, A.J., and J.F. Reynolds. 1988. Statistical Ecology, a Primer on Methods and Computing. John Willey \& Sons. New York.

Marzuki, I. 2007. Studi Morfo-Ekotipe dan Karakterisasi Minyak Atsiri, Isozim, dan DNA Pala Banda (Myristica fragrans Houtt) Maluku [Disertasi]. Sekolah Pascasarjana, Institut Pertanian Bogor. Bogor.

Setiadi, D. 1998. Keterkaitan Profil Vegetasi Sistem Agroforestri Kebun Campur dengan Lingkungannya. Disertasi. Program Pasca Sarjana. Institut Pertanian Bogor. Bogor.

. 2005. Keanekaragaman Spesies Tingkat Pohon di Taman Wisata Alam Ruteng, Nusa Tenggara Timur. J Biodiversitas 6(2) : 118-122.

Soegianto,A. 1994. Ekologi Kuantitatif, Metode Analisis Populasi dan Komunitas. Usaha Nasional. Surabaya

Supranto, J. 2004. Analisis Multivariat, Arti dan Interpretasi. : PT. Rineka Cipta. Jakarta.

Suryana, A. 2007. Arah dan Strategi Pengembangan Sagu di Indonesia. Makalah disampaikan pada lokakarya pengembangan sagu Indonesia. Batam, 25-26 Juli 2007.

Syekhfani. 1997. Hara-Air-Tanah-Tanaman. Jurusan Tanah, Fakultas Pertanian, Universitas Brawijaya. Malang. 